\title{
Politics and Ethnicity: Framing Racial Discrimination in Singapore
}

\author{
JAMES GOMEZ
}

\begin{abstract}
Racial discrimination is a global phenomenon that the United Nations seeks to eradicate. In contemporary Singapore, research shows that the basis for racial discrimination is anchored in the role of ethnic identity and how it frames the formulation of policies related to education, employment, housing, immigration and politics. These policies have been formulated and implemented by the People's Action Party (PAP) government that has been in power for over 50 years. When confronted with its racially based policies, the PAP government insists that it follows a tolerant approach towards different races and that it promotes the idea of multiculturalism and meritocracy as a racial equalizer. However, ethnic minorities in Singapore complain they are being discriminated against daily on the basis of their race or religion. They argue that their views are often not given airing in the local mainstream media and they are further prevented from discussing these issues openly due to legislation restricting freedom of expression and assembly on these matters. Given this background, the first visit of a UN Rapporteur on racism to Singapore, at the invitation of the PAP government in April 2010, allowed the city-state's race-based policies to be put in an international spotlight. This study examines the visit of the UN Rapporteur, his initial findings, government and civil society responses, and the significance of this first UN mission. The paper locates its research on racial discrimination in the context of Singapore's political framework and the United Nations' efforts to eradicate racism. It argues that ultimately, policy changes in Singapore can only take place as a result of politically challenging the PAP government.
\end{abstract}

Key words: ethnic identity, racial discrimination, public policy, Singapore, United Nations

\section{Introduction}

...it is absolutely necessary in a free society that restrictions on public debate or discourse and the protection of racial harmony are not implemented at the detriment of fundamental human rights such as freedom of expression and freedom of assembly (OHCHR 2010b). 
Mr Githu Muigai, the UN Special Rapporteur on contemporary forms of racism, racial discrimination, xenophobia and related intolerance, made these remarks at the end of his eight-day mission from 21 to 28 April 2010 to Singapore. He came to the city-state at the invitation of the People's Action Party (PAP) government to dialogue with the authorities and members of civil society and to gather 'first-hand information on the main issues facing people living in Singapore in relation to racism, racial discrimination, xenophobia and related intolerance' (Office of High Commissioner of Human Rights (OHCHR) 2010a).

On the same day that the UN Rapporteur released his preliminary findings, the PAP government took issue with his call for greater freedoms to discuss race-related issues. In a statement released just hours after the one by the UN Rapporteur, the Ministry of Foreign Affairs (MFA) made this point about freedom of expression and its concern over balancing religious and racial harmony:

This balance is only for the Singapore government to determine because only the Singapore government bears the responsibility should things go wrong. The UN bears no such responsibility and we see no reason to take risks for the sake of an abstract principle (Ministry of Foreign Affairs (MFA) 2010).

This article analyzes the UN Rapporteur's week-long visit that covered meetings with official government representatives and civil society, the Rapporteur's initial findings and the PAP government and civil society responses to those findings. The research for the study was undertaken during the week of the UN Rapporteur's visit in Singapore, from 20 to 30 April 2010. Activities included a focus group meeting with $\mathrm{Mr}$ Muigai as part of the Singaporeans for Democracy (SFD) delegation ${ }^{1}$ on 22 April 2010, attendance at the UN Rapporteur press conference on 28 April 2010, interaction with selected civil society groups and tracking local media reports and online postings.

Themes surrounding ethnicity and nation-building in Singapore are a well researched and published area of study. Most works focus on nation-building and the management of ethnic relations in Singapore. Over the last three decades these studies have appeared as single journal articles or as chapters in collections that discuss nation-building and ethnic relations in Southeast Asia. There also have been several reports that look at the state of ethnic relations that are relevant for gauging contemporary racial attitudes in Singapore (Lai 2002; Chin and Vasu 2007). However, the number of works that focus on the actual practice of racial discrimination has been limited (Barr 2009; Barr and Skrbis 2008; Rahim 1998, 2009; Velayutham 2007). 
This study discusses racial discrimination in the context of Singapore's political framework and the United Nations' efforts to eradicate racism. The PAP-led Singapore government claims the city-state is a multiracial society whereby each citizen is provided equal opportunities. Yet it has not signed one of the first human rights treaties, the International Convention on the Elimination of All Forms of Racial Discrimination (1966), nor is Singapore a signatory to the United Nations Amendment to article 8 of the International Convention on the Elimination of All Forms of Racial Discrimination (1992). By analyzing the UN Special Rapporteur's first mission to the city-state, this paper brings in the international perspective to racism research as it relates to Singapore.

\section{UN Special Rapporteur on Racism}

According to the International Convention on the Elimination of All Forms of Racial Discrimination, the term 'racial discrimination' means

any distinction, exclusion, restriction or preference based on race, colour, descent, or national or ethnic origin which has the purpose or effect of nullifying or impairing the recognition, enjoyment or exercise, on an equal footing, of human rights and fundamental freedoms in the political, economic, social, cultural or any other field of public life (United Nations 1966).

In 1993 the UN Commission on Human Rights appointed a Special Rapporteur to examine incidents and related governmental measures on contemporary forms of racism, racial discrimination and xenophobia and related intolerance. In cases of racism and racial discrimination, the Rapporteur is required to make representations to the respective states. Hence, for nearly two decades the UN has been undertaking missions to various countries to assess the state of racial discrimination and to publish reports, which are often disputed by the countries reviewed.

As part of the mandate to investigate racism, the Rapporteur carries out 'fact-finding' visits to two countries a year and also presents a 'country-report' to the UN Human Rights Council and the General Assembly (OHCHR 2007a). These visits are initiated at the invitation of the government of the respective countries. Sometimes such assessment missions are taken unofficially at the invitation of nongovernmental organizations (NGOs), as was the case in Japan when the former Rapporteur Doude Diene undertook trips in 2005 and 2006 at the invitation of the International Movement Against All Forms of Discrimination and Racism (Johnston 2006). Such visits include utilizing the available resources of information and evaluating the mass media 
to get authentic information and reports of allegations against the government and obtaining the government's reaction.

Apart from the country reports, the Rapporteur is required to submit annual or thematic reports to the Human Rights Council and interim reports to the General Assembly. Additionally, the Special Rapporteur exchanges views with other mechanisms and treaty bodies in the UN system so as to enhance their effectiveness and mutual cooperation. The field missions give the Rapporteur the opportunity to collect first-hand information. But these missions are not only meant to be investigative; they are also instigated to identify and recognize the measures already adopted by the respective governments to fight racism and race-related discrimination (OHCHR 2007b).

Additionally, whenever information surfaces indicating that the rights or interests of minorities in a country are being violated, the Rapporteur communicates the facts in the form of an 'allegation letter' or 'urgent appeal' to the respective government. This is kept confidential until it gets published in the annual report, which is submitted to the Commission on Human Rights (OHCHR 2007c). The Rapporteur's appeal to the respective government is intended to get the case investigated so as to help in identifying the contemporary forms of racial discrimination. Adhering to the mandate of the Commission on Human Rights, the Rapporteur can only ask the government to keep the UN updated on the investigation. In practice, states have often resisted or challenged the findings of the Special Rapporteur and this continues to be an issue in the fight against global racial discrimination.

Supplementing this process, in 2001 the World Conference against Racism, Racial Discrimination, Xenophobia and Related Intolerance took place in Durban, South Africa and resulted in the Durban Declaration and Programme of Action. In 2009, the Durban Review Conference, titled the World Conference Against Racism (WCAR), also known as Durban II, took place at the United Nations Office in Geneva, Switzerland. In both meetings leading countries such as the US and those from Europe and Israel did not participate in the meetings or sent only junior delegations, citing the presence of anti-Semitism and a proposal for laws against blasphemy as reasons. Racism continues to be a problem many governments are reluctant to directly address because of the associated political consequences.

Against this contested background of UN efforts to combat racism, $\mathrm{Mr}$ Githu Muigai was appointed Special Rapporteur on racism and racial discrimination in 2008. He is the third mandate holder since its inception 
in 1993. Muigai is a Kenyan national and a lawyer, an associate professor at the University of Nairobi and senior partner in Mohammed Muigai Advocates in Kenya. Before visiting Singapore he had been to Germany and United Arab Emirates on similar missions. The visit of Mr Muigai was the first visit by a UN Special Rapporteur to Singapore.

\section{UN Rapporteur on Racism Visits Singapore}

The UN team of Mr Githu Muigai, the UN Special Rapporteur, and Ms Anh Thu Duong, the Associate Human Rights Officer, Special Procedures Division, OHCHR in Geneva, arrived in Singapore on 20 April 2010. Prior to the mission, Ms Anh had been writing to different agencies, groups and individuals to set up meetings in Singapore. In order to facilitate the information gathering, the $\mathrm{OHCHR}$ representatives in particular contacted civil society organizations active in the area of racial intolerance and minority communities to assist them in gathering the details regarding ground realities before the arrival of the UN Rapporteur. ${ }^{2}$

On the first day of his visit, Mr Muigai met the Minister for the Environment and Water Resources who is also the Minister-in-charge of Muslim Affairs, Mr Yaacob Ibrahim. As reported in the local mainstream daily, the two officials discussed the enhanced living style of people in Singapore and how the system recognizes their potential and allows them to rise, irrespective of their ethnic background. Mr Ibrahim also highlighted the government's commitment to meritocracy and multiracialism (The Straits Times, 22 April 2010). At the official level, Mr Muigai was also scheduled to meet with Minister for Foreign Affairs, Mr George Yeo, Minister for Community Development, Youth and Sports, Dr Vivian Balakrishnan, Minister for Law and Second Minister for Home Affairs, Mr K Shanmugan and Chief Justice Chan Sek Keong (The Straits Times, 20 April 2010). He also received briefings from government ministries, the Courts and the Presidential Council for Minority Rights. Mr Muigai also met various religious leaders and leaders of ethnic self-help groups. These meetings were widely publicized in the local mainstream media (The Straits Times, 23 April 2010).

Mr Muigai also met with representatives of civil society, ${ }^{3}$ including community members, academics, lawyers and private individuals. Most of these meetings were conducted privately with very little coverage in the mainstream media. Some groups, such as the Think Centre and the Singapore Democratic Party (SDP), reported their meetings on 
their own or on other websites. Think Centre, regarded as Singapore's oldest registered political society, met the UN team and handed them a report covering a variety of issues that affect Singaporeans. Some of the issues covered included maintenance of the Religious Harmony Act, ethnic quotas for home ownership of public housing, and the Sedition Act and Undesirable Publications Act (FORUM-ASIA 2010). The SDP chose to highlight the discrimination faced by minority communities in Singapore. In particular, the SDP emphasized the marginalization and discrimination faced by the Malay Muslim community in Singapore (Shamin 2010).

The meeting with the NGO Singaporeans for Democracy (SFD) received some local media coverage and was reported extensively online by alternative media. The meeting was a result of prior arrangements with the Special Procedures Division at the OHCHR. A group of SFD members submitted an extensive report to the rapporteur to acquaint him with the prevailing situation related to race and ethnicity issues in Singapore. The report attempted to bring the UN official's notice to the existing racism in Singapore in the guise of multiculturalism and meritocracy (SFD 2010b). Furthermore, SFD representatives pointed out that public policy in Singapore is influenced by race and this has adversely resulted in the consciousness of an individual's racial identity. Specifically, the SFD report stated that the inclusion of one's race on the Singaporean Identity Card has accentuated racial categorization, which has largely contributed to racial discrimination among various ethnic groups.

Mr Muigai's visit raised high expectations among the civil society members as it provided them an opportunity to communicate the dayto-day issues of racial discrimination felt at the grassroots level. The PAP government representatives, on the other hand, were emphasizing its 'best practice model' and how racial harmony has been achieved in Singapore through its policy of meritocracy.

\section{UN Special Rapporteur's Press Release}

At the end of his visit on 28 April 2010, Mr Muigai held a press conference at a local hotel. There he acknowledged some of the initiatives taken by Singapore to maintain racial harmony. He noted the work done to maintain social harmony by the National Integration Council, National Steering Committee on Racial and Religious Harmony, The People's Association, One People, and the Inter Racial and Religious Confidence 
Circles (OHCHR 2010b). Expressing appreciation to the Singapore Government for its 'cooperation and openness' in the organization of his visit, Mr Muigai reiterated that he came without any preconceived notions. He also reaffirmed the agenda for his visit, which was to get a better understanding of Singaporean society, to conduct constructive dialogue with the government representatives and civil society partners, to identify the 'best practices' followed by the Singapore government that could be held up as a model for the international community, and above all, preparation of an objective report.

After the above opening remarks, Mr Muigai went into the more substantial part of his comments. He began by noting that there were restrictions on free speech preventing open discussion on issues related to race and religion. He stressed the importance and necessity of public debates and discourse in a free society, adding that racial harmony cannot be achieved by compromising these fundamental rights. He suggested that these legal restrictions be re-examined so as to provide space for the different ethnic groups to exchange ideas and to find solutions for issues creating problems (OHCHR 2010b). He said that as a result of these restrictions, blind spots to some of the government policies have arisen and these are contributing to racial and other discrimination. He then spent the remaining part of his press conference highlighting specific blind spots in some of the PAP government's policies.

He started out by citing the issue of race on Singapore citizens' identity cards. He said that including race on the identity cards accentuated racial difference that contributed to racially based policies, which then led to racial discrimination. As multiculturalism and inter-racial marriages increase, it has also created confusion over accessing self-help groups that are organized on ethnic lines. Group Representation Constituencies (GRC) were purportedly created to make sure that minorities receive equal political representation, but in actual practice, the Rapporteur noted, they have ingrained the status of the minority community in Singapore and furthered their institutionalization (OHCHR 2010b). He therefore recommended eliminating race from national identity documents. After this overarching recommendation, Mr Muigai went on to make comments and recommendations on the ethnic dimensions of policies related to education, employment, housing, immigration and politics.

On the housing issue, the Rapporteur picked up on the 1989 Ethnic Integration Policy and urged more flexibility in the existing ethnic quotas in each state-subsidized apartment block and neighbourhood. He further 
added that though this policy was initiated to prevent the emergence of specific ethnic majority neighbourhoods, with the passage of time this policy has caused inconvenience to the people of minority communities who wish to buy or re-sell their accommodation. Mr. Muigai pointed out that education programmes in Singapore are well in place to promote tolerance and respect among various communities. But referring to the free national education programme for Malay students he noted that at present the system does not take into account the disadvantage caused by the historical inequalities in the Malay community. Turning to the Special Assistance Plan (SAP) schools, Mr Muigai pointed out that in practice they favour Chinese culture and Mandarin language and add to the marginalization of minorities (OHCHR 2010b).

Regarding policies related to local employment, the Rapporteur pointed to language discrimination against Indian and Malay communities in the employment sector. He also added that the Malay community is underrepresented in senior positions at key institutions, which is not reflective of the ethnic diversity in Singapore. In relation to the employment of foreign workers, the Rapporteur noted the Ministry of Manpower's (MOM) 'approved source country' policy for recruiting workers. This, Mr Muigai argued, can perpetuate negative stereotypes against migrant workers of a specific country (OHCHR $2010 \mathrm{~b}$ ). This could also lead to cases of hidden favouritism in the employment system. Related to the issue of foreign workers was that of the PAP government's immigration policy. Mr Muigai noted that there was resentment in Singapore over the recent waves of immigrants and encouraged the government to formulate immigration-related policies in a more open and transparent manner.

On the legal and institutional front, Mr Muigai raised the issue that Singapore has yet to sign the International Convention on the Elimination of All Forms of Racial Discrimination, the International Covenant on Civil and Political Rights, the International Covenant on Economic, Social and Cultural Rights, as well as the International Convention on the Rights of All Migrant Workers and Members of Their Families. He requested that the government comply with these international conventions. Mr Muigai also pointed to the Durban Declaration and Programme of Action as well as the Outcome Document of the Durban Review Conference as useful frameworks for the PAP government to engage (OHCHR 2010b). He encouraged the government to review the Presidential Council for Minority Rights (PCMR) so as to make it independent and to give it power to consider any public policy on its 
own initiative. To sum up his discussion on legal issues affecting minority groups, Mr Muigai suggested that the government take measures in legal terms to eliminate and prohibit discrimination on the basis of ethnic identity and county of origin.

His press statement had a mixed tone. On one hand it acknowledged the government policies and regulations for maintaining racial and religious harmony. Mr Muigai noted the cohabitation and interaction of people of diverse ethnic, religious and cultural identities. He found that Singapore as a society, despite the religious riots of a few decades earlier, was an example of peaceful coexistence of the different ethnic groups. On the other hand, the Rapporteur felt more freedoms were now appropriate to discuss contemporary challenges of racial discrimination facing Singapore society. He suggested that current legislation be relaxed or modified and new legislation be implemented. He urged the PAP government to take reformative actions to bring about an overall harmonious society. His suggestions for corrective actions reflected the inputs he received at meetings with civil society groups and individuals. This allowed voices, apart from the government's, to be reflected in his initial findings.

\section{PAP Government and Civil Society Responses to the UN Rapporteur}

If we are to understand the responses to the UN Special Rapporteur's first mission's initial findings, it is instructive to go to the beginning of the Rapporteur's visit when both the Singapore government and the $\mathrm{UN}$ issued their press releases. The statement issued by the UN Office of the High Commissioner of Human Rights stated that Mr Muigai, in addition to speaking with government officials, would also consult nongovernmental organizations (NGOs), community members, academics and other people working on issues of racial discrimination (OCHCR 2010a).

A Singapore Ministry of Foreign Affairs (MFA) statement issued the same day regarding Mr Muigai's visit and reported the next day had a different slant: 'Singapore welcomes the opportunity to share with the UN, through Mr Muigai, our experiences and efforts at combating racism and racial discrimination and our policies to encourage racial and religious tolerance and harmony' (The Straits Times, 20 April 2010). This set the stage for the different set of responses to the UN Special Rapporteur's initial findings. 
The MFA was focused on defending the PAP government's 'best practices' and policies, which it felt was well in place to maintain racial harmony within the city-state. The tone of the MFA response was harsh and it did not agree with any of the Rapporteur's findings. The MFA statement not only disagreed with Mr Muigai's findings overall, it also added that it would wait for the final report to respond further (MFA 2010). The MFA rejected all of Mr Muigai's suggestions, which gave the impression that perhaps the PAP government had only invited him to highlight and reaffirm the practices they considered 'best practices' so that they could be shared with the international community.

The main strategy in the MFA press release was to personalize the civil society findings of the Rapporteur and to attack Mr Muigai personally or negate his findings. The MFA release also used the words of the Special Rapporteur against him, for instance on the suggestion to remove race from Singaporean identity cards, the MFA press release mentioned that the presence of different races in Singapore could not be denied and that Mr Muigai had reportedly confirmed in an earlier meeting that there is no 'correct approach to this issue' (MFA 2010). On the issue of the marginalization of the Malays, the MFA responded by saying that 'great progress has been made in the last decades', which Mr Muigai himself was reported in the media to have acknowledged. The MFA release further stated that even the president of the Islamic Religious Council of Singapore (MUIS), Mr Mohd Alami Musa, in his meeting with Mr Muigai, reflected 'a sense of pride' and rejected the need for any 'special provisions' for the Malay community.

The MFA also 'emphatically' disagreed with the Rapporteur's suggestion to bring flexibility to the Sedition Act and the Penal Code so as to allow freedom of expression by citizens on ethnic issues. The MFA response stated that such issues are sensitive and it is the PAP government's responsibility to maintain a balance between 'free speech and racial harmony' (MFA 2010). The MFA response obliquely hinted at the UN as being only a recommendatory body without any power to dictate terms. At the same time it asserted the position of the PAP government as being a responsible and accountable one. The tone of the MFA statement also indicated that the PAP government would not be interested in complying with any of the proposed human rights conventions, stating it would only accede to them if it finds some 'substantial value' in doing so.

The release of the MFA statement hours after the Rapportuer's press conference was to negate and reduce the full impact of Mr Muigai's 
initial findings. The MFA seemed more interested in defending the PAP government's official position and in no way appeared interested in accepting any of the suggestions and recommendations. The MFA instead asserted that given the ground realities of the city-state and the distribution of ethnic communities, the steps taken by the government were appropriate for Singapore. According to the MFA, the PAP government's measures to ensure racial harmony have been successful and without problems. The MFA statement showed no flexibility in accepting any criticism of existing policies and practices. In fact, it seemed to take no meaningful interest in the suggestions of the Rapporteur.

Other the hand, the civil society response was different. Singaporeans for Democracy also issued a press release on the same day to state that it would establish a racial discrimination monitoring committee that would run with immediate effect and would operate until the Rapporteur's report was issued (SFD 2010a). Further, it took the Rapporteur's recommendation on race identification on identity cards and turned it into a Facebook page advocacy project that had 300 members ${ }^{4}$ joining in 24 hours (The Online Citizen 2010). SFD decided to focus on the issue of race identification as a key policy issue and tried to generate attention around it. This online project was set up as part of SFD's efforts to monitor the report of the UN Special Rapporteur on racism; the Rapporteur will present his findings on Singapore before the UN Human Rights Council in Geneva (in June 2011) and the UN General Assembly in New York (in November 2011).

\section{Significance of the UN's First Mission to Singapore}

The value of the UN Rapporteur's first mission to Singapore was in pointing out the blind spots in the PAP government's racially based policies. It puts these policy blind spots under an international spotlight through the auspices of the UN. Although most of the issues have been identified and highlighted in the past by civil society groups and in academic analysis, the independence of the UN mission lends credibility to the issues. The PAP government can no longer try to ignore the problems highlighted by the UN Special Rapporteur within the UN framework without being subjected to some level of international criticism and on public record.

But based on the response of the PAP government to the UN Special Rapporteur's initial findings, observers can predict how Singapore 
government officials will respond to the Rapporteur's final report. The PAP government is likely to maintain that they are the best judge of how to maintain the balance between freedom of expression and racial harmony. If the initial governmental response is anything to go by, it is likely to reject the bulk of the suggestions on the basis that they are not feasible in Singapore. It is apparent from the government's response to Mr Muigai's suggestions that the government holds a strong ideological position about the value of meritocracy and is not prepared to acknowledge the existence of policy blind spots or agree to policy revisions. Any concession to look into a policy change following the Rapporteur's final report will be more of a public relations exercise to appease the UN community and international media, rather than a real effort to reassess policy.

The UN Special Rapporteur's visit also brought to the attention of Singapore's civil society the UN mechanisms through which local groups could have their views recorded. Although the Rapporteur met with civil society groups on an individual basis, there was little cross communication or prior coordination between the different groups in Singapore. It would have been better if civil society groups had met together prior to the Rapporteur's visit to prepare some form of joint report with the additional option of submitting individual reports where appropriate. In spite of this shortcoming, the visit has increased interest among local civil society groups in UN mechanisms and awareness of their ability to contribute inputs into the different processes. Hence, several groups in late 2010 cooperated to formulate joint reports for submission to the Universal Periodic Review where Singapore is up for review in $2011 .^{5}$

Apart from the media releases immediately prior to the Rapporteur's visit, there was little or no other pre-publicity about the important first mission to Singapore. Publicity was kept to a minimum, ensuring that the visit would remain a low-key affair. But the UN Rapporteur's visit created some local attention in the mainstream media and much more in the new media landscape. There was considerable enthusiasm in discussing the UN Special Rapporteur's visit and its possible impact. For instance, when the media reports began to emerge and some civil society groups began to publicize their own meetings with the Rapporteur, online users were active in sharing their opinions. The majority of the web commentary questioned the government's stand and argued instead that there was everyday racism in Singapore. The internet commentaries showed that the PAP government that controls the media can no longer 
frame and control the discussion of race-related issues. The discourse on the internet helped to show that the PAP government's 'racial harmony' is a myth, created by government-controlled media (Journalism SG 2010).

Finally it has to be acknowledged that while the UN mission is helpful in putting the international spotlight on some of the policy blind spots discussed above, in reality policy changes in Singapore can only be implemented through political reform. For this to happen there has to be a political challenge to the PAP government to carry out policy changes that seek to address some of the issues related to racial discrimination in Singapore. Without a political challenge to the PAP government it is unlikely there will be significant policy shifts in the city-state in the near to medium term.

\section{Conclusion}

Many of the recommendations made by Mr Muigai, the UN Special Rapporteur on racism, are not new. These have been raised over the years by opposition parties and civil society groups and have been discussed extensively in published academic works. As seen by the PAP government's response to the Rapporteur's initial recommendations, it is expected that Singapore officials at the UN meetings will be seeking to respond similarly to Mr Muigai's final report before the UN Human Rights Council in Geneva (in June 2011) and the UN General Assembly in New York (in November 2011). Even though the PAP government actively disagreed with the initial recommendations and will likely do so of the final report, the value of these policy suggestions lies in their appearing in a UN report and in an international domain. While in Singapore the PAP government may try to control and frame the issue of racial discrimination via its influence over the local mainstream media, it cannot do the same in an international setting. Researchers working on issues of racial discrimination need to include this international dimension in future studies. While the UN may put these issues under an international spotlight, researchers also need to understand that ultimately changes to these policies can only take place by politically challenging the PAP government.

James Gomez is presently Deputy Associate Dean (International) and Head of Public Relations, School of Humanities, Communications and Social Sciences at Monash University in Australia. (james.gomez@monash.edu) 


\section{NOTES}

1 The author is also the founding Executive-Director of Singaporeans for Democracy (http://sfd.sg).

2 Email to Singaporeans for Democracy (SFD) on 14 April 2010.

3 Here the term civil society refers to those groups registered with the Registrar of Societies in Singapore whose activities are aimed to be independent of the PAP government. For a fuller discussion of civil society in Singapore see also Lyons and Gomez (2005).

4 At the time of writing the Facebook group had nearly 1000 members.

5 Groups such as Maurah and Think Centre, in 2010, convened separate joint civil society meetings to find ways to draft joint submissions to the Universal Periodic Review process. Singaporeans for Democracy was a contributing member to both these groups.

\section{REFERENCES}

Barr, M. D. 2009. Lee Kuan Yew: The Belief Behind the Man. Kuala Lumpur: New Asian Library.

- and Z. Skrbis 2008. Constructing Singapore: Elitism, Ethnicity and the Nation-building Project. Copenhagen, Denmark: Nordic Institute of Asian Studies Press.

Chin, Yolanda, and Norman Vasu 2007. Ties that Bind and Blind: A Report on Inter-racial and Inter-religious Relations in Singapore. Centre for Excellence for Security Studies, S. Rajaratnam School of International Studies, Nanyang Technological University, Singapore. Accessed 18 August 2010 at http:/ / www.rsis.edu.sg/cens/ publications/ reports/RSIS\%20Social\%20resilience\%20report.pdf.

FORUM-ASIA 2010. 'Singapore-UN envoys visits for fact finding mission on racism', 3 May 2010. Accessed 16 July 2010 at http://www.forum-asia.org/index. php?option=com_content\&task=view\&id=2535\&Itemid $=130$.

Journalism SG 2010. 'Activists tell UN that racial harmony here is a myth', 23 April. Accessed 18 August 2010 at http://journalism.sg/2010/04/23/activists-tell-unthat-racial-harmony-here-is-a-media-myth/.

Johnston, Eric 2006. 'Racism rapporteur repeats criticism'. Japan Times Online, 18 May. Accessed 27 August 2010 at http:/ / search.japantimes.co.jp/cgi-bin/nn20060518a6. html.

Lai Ah Eng 2002. 'Report on IPS Research Forum on Ethnic Relations in Singapore'. Institute of Policy Studies, Singapore. Accessed at http://www.spp.nus.edu.sg/ ips/docs/reports/rp_erpforumreport.pdf.

Lin, Rachel 2010. 'UN racism expert meets local leaders'. The Straits Times, 23 April.

Lyons, Lenore, and James Gomez 2005. Sojourn: Special Focus on Democracy and Civil Society: NGO Politics in Singapore, 20, no. 2. Singapore: Institute of Southeast Asian Studies.

Ministry of Foreign Affairs (MFA) 2010. 'MFA's Response to the Press Statement of Mr Githu Muigai, UN Special Rapporteur on Contemporary Forms of Racism, Racial Discrimination, Xenophobia and Related Intolerance', 28 April. Accessed 16 July 2010 at http:/ /app.mfa.gov.sg/2006/press/view_press.asp?post_id=6002.

Office of the United Nations High Commissioner for Human Rights (OHCHR) 2010a. 'First mission to Singapore by UN expert on Racism/Xenophobia', 19 April. Accessed 19 July 2010 at http://www.ohchr.org/en/NewsEvents/Pages/DisplayNews. aspx?NewsID=9968\&LangID=E. 
- 2010b. 'Press Statement of UN Special Rapporteur in Singapore', 28 April. Accessed 16 July 2010 at http://www.ohchr.org/en/NewsEvents/Pages/DisplayNews. aspx?NewsID=10002\&LangID=E.

- 2007a. 'Overview of the Mandate'. Accessed 14 July 2010 at http:/ /www2.ohchr. org/english/issues/racism/rapporteur/overview.htm.

- 2007b. 'Country Visits'. Accessed 14 July 2010 at http:/ / www2.ohchr.org/ english/ issues/racism/rapporteur/visits.htm.

-2007c. 'Individual Complaints'. Accessed 14 July 2010 at http:/ / www2.ohchr.org/ english/issues/racism/rapporteur/complaints.htm.

Rahim, Lily Zubiadah 2009. Singapore in the Malay World; Building and Breaching Regional Bridges. London: Routledge.

- 1998. The Singapore Dilemma: The Political and Educational Marginality of the Malay Community. New York: Oxford University Press.

Shamin, Muhammad 2010. 'Discrimination in Singapore is institutionalised'. Singapore Democratic Party, 27 April. Accessed 20 July 2010 at http://yoursdp.org/index. $\mathrm{php} /$ news/singapore/3644-discrimination-in-singapore-is-institutionalised.

Singaporeans for Democracy (SFD) 2010a. 'SFD to establish racial discrimination monitoring committee', 28 April. Accessed 16 August 2010 at http:/ /sfd.sg/content/ sfd-establish-racial-discrimination-monitoring-committee.

- 2010b. 'SFD written submission to UN Special Rapporteur', 22 April. Accessed on 16 July at http://sfd.sg/content/sfd-written-submissionun-special-rapporteur.

The Online Citizen 2010. 'Group wants "race" removed from NRIC', 5 May. Accessed on 18 August 2010 at http://theonlinecitizen.com/2010/05/group-wants-raceremoved-from-nric/.

United Nations 2009. Durban Review Conference. Accessed 27 August 2010 at http:/ / www.un.org/durbanreview2009/.

- 2001. World Conference against Racism, Racial Discrimination, Xenophobia and Related Intolerance. Accessed 27 August 2010 at http:/ / www.un.org/WCAR/.

- 1966. International Convention on the Elimination of All Forms of Racial Discrimination. Accessed 27 August 2010 at http://www2.ohchr.org/english/ law/cerd.htm.

Velayutham, Selvaraj 2007. 'Everyday Racism in Singapore'. Centre for Research on Social Inclusion, Macquarie University, Sydney, Australia. 